\title{
Gwynaeth McIntyre, Sarah McCallum (eds.), Uncovering Anna Perenna: A Focused Study of Roman Myth and Culture, (Bloomsbury Classical Studies Monographs), Bloomsbury Academic, London-New York-Oxford-New Delhi-Sydney 2019, 242 pp.; ISBN 978-1-3500-4843-0
}

The character of the goddess/nymph Anna Perenna or Anna Peranna (Varro, Men. fr. 506 Astbury; Gell. NA 16.7.10) is rather mysterious and infrequently appears in the Roman literature and mythology. Most probably, the worship originated in Italy, and was principally related to the beginning of the new year, as indicated by the second part of her name: peranna. This is observed both in Latin, where perennis $<$ per - atni means 'per annum', as well as in other Italian languages from the Osco-Umbrian languages, where the Umbrian -acnu, or Oscan-akenei also means 'annual'. Also the time of the holiday devoted to Anna Perenna, namely the first day of the year, or the Ides of March (15 March), as testified to by the inscriptions (CIL VI 2299, 2301-2302) found most probably at the place of her worship (nowadays Piazza Euclide, near the former via Flaminia - CIL VI 2299: Feriae Annae Perennae via Flam[inia] ad lapidem prim[um]) can point to the connection between the holiday and the beginning of the Roman year. ${ }^{1}$ As pointed out by Macrobius, ${ }^{2}$ the worship had both private and public-sacral nature, as it was related to the important change for the national state brought about by the beginning of the year.

The mentions related to Anna Perenna are rather late in the Roman literature, as the first direct mentions come from the works by authors from the late Republic (M. Terentius Varro in Menippean Satires ${ }^{3}$ ), and principally the writers from the times of Augustus' rule: P. Vergilius Maro in his epic Aeneid, and P. Ovidius Naso in Fasti. Later authors recall the figure of Anna while referring to the writings by the aforementioned Virgil and Ovid; these include Silius Italicus in his epic Punica, and the commentator of Virgil's Aeneid, Maurus Servius Honoratus.

The later goddess/nymph Anna Perenna in the ancient works mainly appears in the context of her alleged relations with Aeneas' stay in Carthage, as Aeneas, while fleeing

Cf. Mart. Epigram. 64.16-18.

2 Macrob. Saturn. 1.12.6: eodem quoque mense et publice et privatim ad Annam Perennam sacrificatum itur, ut annare perannareque commode liceat.

3 Varro, Men. fr. 506 Astbury: ...te Anna ac Peranna, Panda, te calo, Pales, Nerienes <et> Minerva, Fortuna ac Ceres... 
from Troy destroyed by the Greeks, stopped by at the court of Queen Dido, Anna's sister (Virgil, Ovid, Silius Italicus). Anna's role in the tragically ended relationship between Aeneas and Dido is rather unclear, but the authors mainly point to her foreign, Punic origin. This issue was also raised in Book VIII of Punica by Silius Italicus, while referring to Anna's origin from Carthage, whereby the author states that, convinced by goddess Juno, Anna was to appear to Hannibal and encourage him to deal with the Romans during his campaign in Italy before the Battle of Cannae in $216 \mathrm{BCE}$. On the other hand, the aforementioned works point to the issue of Anna's arrival in Italy, where she found shelter for a brief time after she had fled from Carthage endangered by the enemies. Jealousy of Aeneas' wife, Lavinia, forced Anna to flee again, which escape ended in the Numicius River in Latium, where Anna turned into a nymph (apotheosis), becoming a goddess related to the aquatic environment.

Another aspect of the worship includes her relations, pointed out by ancient authors (Ovid), with the Roman plebeians and their first secession at Mons Sacer in 494, when Anna from of the Latin Bovillae was to give away the cakes she baked to the hungry rebels; because of this, when the people returned to Rome, she was commemorated with a statue (signum perenne) in the City! This may be related to the fact that the goddess was associated with fertility. Also the celebrations to worship the goddess, principally known from Ovid's reports, were of rather ludic nature, with laidback atmosphere filled with playfulness, but also eroticism. They did not take place at the temple, but in open areas around the Tiber outside the city (Ovid, M. Valerius Martialis). Therefore, we do not only deal with the worship of a goddess related to the beginning of the year, but also of fertility, and the celebrations may testify to much earlier origin of the worship.

All these issues were discussed in the reviewed interdisciplinary study entitled $U n$ covering Anna Perenna: A Focused Study of Roman Myth and Culture published by Bloomsbury Academic and edited by Gwynaeth McIntyre and Sarah McCallum. Both editors are American scholars dealing with the broadly understood political and social history, as well as religions of Rome (G. McIntyre), ancient literature and classical languages (S. McCallum) at the universities of Otago and Arizona, respectively. The introduction ("Introduction: Anna and the Plebs: A Synthesis of Primary Evidence," pp. 1-16) was written by an outstanding expert in the history of ancient Rome, professor emeritus of University of Exeter, Timothy P. Wiseman, who already dealt in the worship of Anna Perenna in his research. ${ }^{4}$ The introduction is preceded by the Preface, List of Abbreviations, and Information on the Authors. The volume reviewed comprises four parts divided into nine chapters, each written by a different researcher. Part One, entitled "From Carthage to Rome" includes three chapters: Sarah McCallum,"Rivalry and Revelation: Ovid's Elegiac Revision of Virgilian Allusion" (pp. 19-36), James S. McItyre, "Calendar Girl: Anna Perenna Between the Fasti and the Punica" (pp. 37-53) and Gwynaeth McIntyre, "Not Just Another Fertility Goddess: Searching for Anna in Art" (pp. 54-67). Part Two, entitled "Anna and Her Nymphs," also includes three chapters: David J. Wright, "Anna, Water and Her Imminent Deification in Aeneid 4" (pp. 71-82), A. Everett Beek, "How to Become a Hero: Gendering the Apotheosis of Ovid's Anna

4 T. P. Wiseman, The Cult Site of Anna Perenna: Documentation, Visualisation, Imagination, in: L. Haselberger, J. Humphrey (eds.), Imaging Ancient Rome: Documentation - Visualisation - Imagination, Portsmouth, Rhode Island 2006, 51-62. 
Perenna" (pp. 83-93), and Anna Blennow, "Instability and Permanence in Ceremonial Epigraphy: The Example of Anna Perenna" (pp. 94-110). Part Three, entitled "Champion of the Plebs," comprises two articles: Teresa Ramsby, "Ovid's Anna Perenna and the Coin of Gaius Annius" (pp. 113-124), and Carole Newlands, "Infiltrating Julian History: Anna Perenna at Lavinium and Bovillae (Ovid, Fast. 3.523-710)" (pp. 125-146). The last part, Part Four, entitled "The Afterlife of Anna Perenna" includes just one article: Justin Hudak, "Riverrun: Channelling Anna Perenna in Finnegans Wake" (pp. 149162). The volume contains collective endnotes, bibliography, and two indices: locations and general, as well as several illustrations listed at the beginning.

In the "Introduction: Anna and the Plebs: A Synthesis of Primary Evidence," T. P. Wiseman presents the sources mentioning Anna Perenna. The author does not limit himself to literary sources. He also points to inscriptions referring to the goddess, and attempts to place her worship in the context of socio-political and ideological transformations at the decline of the Republic and the early years of the Empire.

Part One, "From Carthage to Rome," attempts to revise various concepts referring to the origin of Anna Perenna's worship, by confronting the reports by Virgil (Aeneid) and Ovid (Fasti). At the same time, attention is drawn to the causes for their different perspective of the goddess by Sarah McCallum, and to the attempt of building another story by Silius Italicus in his Punica, where Anna Perenna with her Roman-Punic identity has an important role as a person contributing to convincing Hannibal to the Battle of Cannae, which was one of the major Roman defeats, but also an important stage in Rome's building the foundations for its supremacy over the world, which perhaps would not have been achieved otherwise, as presented by James S. McItyre. Gwynaeth McIntyre, attempts to interpret the presentations of most probably Anna Perenna in bas-reliefs at the Altar of Augustan Peace (Ara Pacis) and the fragment of the altar found in Carthage (from the same period). It also points to the important ideological function the goddess should have in Augustus' policy as a symbol of peace and welfare, which she brought to Rome after the period of civil wars.

Part Two, "Anna and Her Nymphs," focuses on Anna Perenna as a goddess associated with water, and on how Dido's sister transformed into a water goddess/river nymph. In his article David J. Wright perceives a relation between Anna Perenną and Juturna/ Diuturna, principally by referring to fragments of Virgil's Aeneid, whereas for A. Everett Beck Anna's apotheosis referred to by Ovid in Fasti is not just a regular transformation of a woman into an animal, island, or a plant, as known from his Metamorphoses, but bringing her to the rank of a higher being than she was during her life, a goddess, a heroine. Anna's perception through inscriptions ( $A E$ 2003, 251-253) referring to her worship is proposed by Anna Blenow. When analysing votive inscriptions devoted to the worship of Anna Perenna (tabellae defixionum), she concludes the inscriptions can tell us a lot about the celebrations of the goddess, which could take the form of competitions, playing and games. Another aspect raised by the Author is that the preserved inscriptions can also testify to changes in the organisation of the celebrations of the goddess, and the presence of other gods worshiped at the time. According to A. Blenow, epigraphic material devoted to Anna and the rituals related to her resembles inscriptions devoted to the Arval Brethren. 
The chapters in Part Three ("Champion of the Plebs"), focus on Anna as a goddess whose worship is related to the Roman populus. Teresa Ramsby analyses the coin of Gaius Annius, the reverse of which probably depicts the goddess. The Author interprets Anna's depiction on the coin minted by Gaius Annius, who supported L. Cornelius Sulla, but who originated from a plebeian family, as an important element of his propaganda during the conflict in Spain where Annius, as a proconsul on Sulla's behalf, was ordered to confront the populares led by Quintus Sertorius in 82/81 BCE. Carole Newlands, expert in Ovid's literature, analyses the fragment of Fasti 3.525-710, where the Roman poet presents the myth of Anna Perenna in the context of the events taking place during the Ides of March of 44 BCE. She clearly points out that Ovid does not focus on the assassination of Gaius Julius Caesar, which was a crucial event to Rome, but principally for Gaius Octavius, later Augustus. This was the event of major importance to Gaius Octavius and his policy after his victory over Marcus Antonius. This moment and its consequence, including the apotheosis of the assassinated Caesar as god, was one of the fundamental pillars to legitimise his power, and it had a very strong presence in all acts of the ruler who wished to emphasize his right to rule Rome. In fact, in the titlerelated fragment of his Fasti, Ovid goes away from these events while focusing on Anna Perenna and the former celebrations of her holiday, which used to take place in Rome exactly on the Ides of March. The Author suggests deliberate action of the poet, whose verses in Fasti may present the feelings of a part of the Roman society with respect to the eastern origin of the habit to worship the ruler. This may also be a camouflaged irony with respect to such actions, to contest Augustus' actions who shaped the new Roman memory, identity and perception of the past (historical politics!).

The last part ("The Afterlife of Anna Perenna") presents the reception of the myth of the goddess/nymph in the contemporary literature. It affected the work of the 20thcentury author, James Joyce, Finnegans Wake.

This new book by Bloomsbury Academic thus presents very interesting and thorough study on Anna Perenna, a mythological character that is not well-known to the public. Particular researchers have presented the image of the goddess/nymph while relying on various sorts of source materials, and analysed the nature of her worship in every possible aspect. At the same time, attention was drawn to the historical period (turn of the Republic and the Empire), the political background at which the worship of Anna Perenna was depicted by the ancient authors (Varro, Vigil, Ovid, Silius Italicus), as well as its reception in the contemporary literature at the example of James Joyce.

Maciej Piegdoń

iD http:/orcid.org/0000-0002-1720-5913

Jagiellonian University in Kraków 